\title{
Characterization of ATM and DNA-PK wild-type and mutant cell lines upon DSB induction in the presence and absence of CK2 inhibitors
}

\author{
BIRGITTE B. OLSEN ${ }^{1}$, GERHARD FRITZ ${ }^{2}$ and OLAF-GEORG ISSINGER ${ }^{1}$ \\ ${ }^{1}$ Institute for Biochemistry and Molecular Biology, University of Southern Denmark, 5230 Odense, Denmark; \\ ${ }^{2}$ Institute of Toxicology, Heinrich Heine University Düsseldorf, 40225 Düsseldorf, Germany
}

Received July 21, 2011; Accepted August 30, 2011

DOI: $10.3892 /$ ijo.2011.1227

\begin{abstract}
Protein kinase CK2 is involved in several cellular processes and has lately also been linked to the DNA damage response through phosphorylations and interactions. Herein, we have analysed two sets of mouse cell lines, one pair, which is proficient and deficient in ATM and the other set expressing or lacking a functional catalytic subunit of the DNA dependent protein kinase (DNA-PKcs). Both kinases are implicated in the downstream phosphorylation of the signaling molecules such as BID and AKT1 in response to DNA damage. BID and AKT1 are also targets of CK2, hence the four cell lines were treated with the three established CK2 inhibitors DMAT, TBB and resorufin in the absence and presence of the radiomimetic drug neocarzinostatin, which induces DNA double-strand breaks. We show that there are differences with respect to the effect of the CK2 inhibitors on the phosphorylation of AKT1 at S473 and its downstream target GSK3 $\beta$ as well as between the two sets of cell lines. However, no such change was seen with BID phosphorylation. The most notably difference was the higher expression of CK2 $\alpha^{\prime}$ and CK2 $\beta$ in DNA-PKcs defective cells compared to the DNA-PKcs proficient cells.
\end{abstract}

\section{Introduction}

Protein kinase CK2 is a ubiquitous serine/threonine kinase involved in a large number of cellular processes including proliferation, survival and viability (reviewed in refs. 1,2). Protein kinase CK2 is a tetrameric holoenzyme consisting of two regulatory $\beta$-subunits and two catalytic $\alpha$-subunits. Besides the major catalytic $\alpha$-subunit an additional catalytic subunit $\left(\alpha^{\prime}\right)$ is known, which is primarily detected in brain and

Correspondence to: Dr Olaf-Georg Issinger, Institute for Biochemistry and Molecular Biology, University of Southern Denmark, Campusvej 55, 5230 Odense, Denmark

E-mail: ogi@bmb.sdu.dk

Key words: protein kinase CK2, DNA-PKcs, ataxia-telangiectasia mutated, double-strand break, CK2 inhibitors testes $(3,4)$. The catalytic CK2 subunits share a high degree of homology except for the C-terminal part (5) and not much is known about the functional difference between the two catalytic subunits. Their functions appear redundant, however mice deficient in CK2 $\alpha$ die during early embryogenesis (6), whereas mice deficient in CK $2 \alpha^{\prime}$ appear normal, although the male mice are sterile due to abnormal spermatogenesis (4), suggesting that the two catalytic subunits have functions which can not be substituted by the other.

Within the last decade, a role for CK2 has emerged in the DNA damage response both with respect to single strand breaks (SSBs) but especially in response to DNA double strand breaks (DSBs). Major players in the DNA damage response are members of the phosphatidylinositol-3-kinase (PI3K)-related protein kinase (PIKK) family, including ATM (ataxia-telangiectasia mutated), and DNA-PKcs (DNA-dependent protein kinase catalytic subunit), which are both involved in the response to DSBs and ATR (ataxia- and Rad3-related), which has a role in the response to SSBs originating from replicative stress (reviewed in ref. 7). DSBs are the most deleterious form of DNA damage and can be repaired either through homologous recombination (HR) or non-homologous end-joining (NHEJ), in which DNA-PKcs plays an essential role (reviewed in ref. 8). The exact role of DNA-PKcs in NHEJ remains to be fully elucidated, but cells lacking functional DNA-PKcs are sensitive to DSBs and show impaired DNA repair (9).

Most recently, Olsen et al showed a physiological relationship between DNA-PKcs and CK2 in human glioblastoma cells. Depletion of CK2 strongly inhibits DNA damage-induced autophosphorylation of DNA-PKcs at S2056 as well as repair of DNA double-strand breaks. These results indicate that CK2 plays an important role in modulating DNA-PKcs and provide insights into the mechanisms by which DNA-PKcs is regulated and link CK2 to repair of DSBs (10). Of note, lack of DNA-PKcs both in human and murine cell lines leads to increased expression levels of CK2 2 ', but not CK2 $\alpha$ (11). Upon induction of DSBs, ATM is rapidly activated and phosphorylates a large number of substrates in various pathways of the DNA damage response (reviewed in ref. 12). CK2 physically links the MRE11-RAD50-NBS1 (MRN) complex to damaged chromatin through constitutive phosphorylation of the MDC1 mediator protein $(13,14)$, which also recruits ATM among other to the site 
of DNA damage (15). However, CK2 has also been shown to phosphorylate/interact with other proteins involved in the DNA damage response including p53 (16,17), MDM2 (18), XRCC1 (19), XRCC4 (20), BID (21,22), CHK1 (23), CHK2 (24,25) and AKT1 (26,27).

BID translocates to the nucleus in response to DNA damage and is transiently phosphorylated by ATM at Ser61 and Ser78 (the major site) $(28,29)$. Homozygous BID knockout mice display chromosomal abnormalities and develop a disorder resembling chronic myelomonocytic leukemia $(30,31)$, which indicates that BID plays a role in the DNA damage response and in genomic stability. AKT1 is activated following DSBs through phosphorylation by DNA-PK and PDK1 at Ser473 and Thr308, respectively (32-34). AKT1 knockout mice show impaired DNA damage-dependent induction of the cyclindependent kinase inhibitor p21 and increased apoptosis (34), indicating that AKT1 plays a role in promoting survival in response to DNA damage.

Two pairs of mouse cell lines, a pair of mouse embryo fibroblast cell lines expressing or lacking ATM and a pair of mouse fibroblast cell lines proficient and defective in DNA-PKcs were treated with three different CK2 inhibitors. Many of published results involving CK2 are based on the use of $\mathrm{CK} 2$ inhibitors such as DMAT and TBB, however, some of them have been shown not only to inhibit CK2 but also other kinases including PI3K and DNA-PKcs (35), which might be circumstantial with respect to some of the results obtained. As opposed to DMAT and TBB, resorufin has recently been described as the inhibitor with highest selectivity for CK2. Hence, we have included into our investigations DMAT, TBB and resorufin and monitored their potential effect on the phosphorylation status of BID and AKT1 and the downstream target GSK3 $\beta$ in the absence and presence of the radiomimetic drug neocarzinostatin.

\section{Materials and methods}

Mouse embryonic fibroblasts $\left(\mathrm{ATM}^{+/+}\right.$and $\left.\mathrm{ATM}^{-/}\right)$were provided by P. Leder (Boston, MA). Mouse Balb/c fibroblasts and fibroblasts derived from DNA-PKcs defective Scid mice were provided by K. Biedermann (36). All cell lines were grown in Dulbecco's modified Eagle's medium supplemented with $10 \% \mathrm{FBS}$ at $37^{\circ} \mathrm{C}$ in a humidified atmosphere and under $5 \% \mathrm{CO}_{2}$.

Cells were incubated with $50 \mu \mathrm{M}$ TBB, $25 \mu \mathrm{M}$ DMAT (both from Calbiochem, Nottingham, UK) or $50 \mu \mathrm{M}$ resorufin (KinaseDetect ApS, Odense, Denmark) for $5 \mathrm{~h}$. The last $3 \mathrm{~h}$, where indicated, neocarzinostatin (NCS) (a kind gift of Dr Hiroshi Maeda (Kumamoto University, Japan) was added to a final concentration of $30 \mu \mathrm{g} / \mathrm{ml}$.

Cell extracts and Western blotting. Whole cell extracts were prepared by washing cells extensively in PBS and collecting by centrifugation. Cells were resuspended in cold lysis buffer (50 mM Tris- $\mathrm{HCl} \mathrm{pH}$ 7.5, $150 \mathrm{mM} \mathrm{NaCl}, 1 \%$ Triton-X-100, $10 \%$ glycerol, $1 \mathrm{mM}$ DTT, $30 \mathrm{mM} \mathrm{Na}{ }_{4} \mathrm{PP}_{\mathrm{i}}, 10 \mathrm{mM} \mathrm{NaF}, 1 \mathrm{mM}$ $\mathrm{Na}_{3} \mathrm{VO}_{4}, 100 \mathrm{nM}$ okadaic acid) containing a protease inhibitor cocktail (Roche, Hvidovre, Denmark). Lysates were cleared by centrifugation at $4^{\circ} \mathrm{C}$ for $20 \mathrm{~min}$ at $12,000 \mathrm{x}$ g. Proteins $(15 \mu \mathrm{g})$ were separated by SDS-PAGE and the proteins transferred to a PVDF membrane (BioRad, Copenhagen, Denmark)

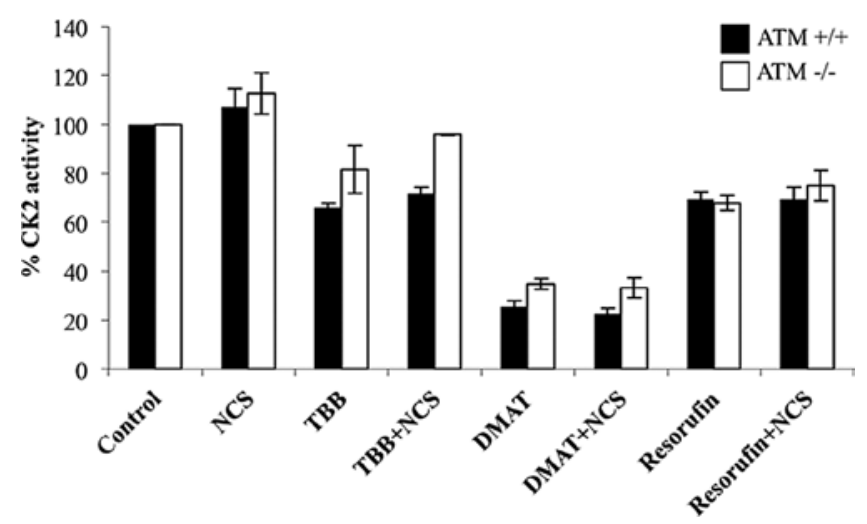

Figure 1. Inhibition of endogenous CK2 by TBB, DMAT and resorufin in the absence and presence of the radiomimetic drug NCS. Mouse embryo fibroblasts $\left(\mathrm{ATM}^{+/+}\right.$and $\left.\mathrm{ATM}^{-/}\right)$were pre-incubated with $50 \mu \mathrm{M}$ TBB or resorufin or $25 \mu \mathrm{M}$ DMAT for $2 \mathrm{~h}$ before adding $30 \mu \mathrm{g} / \mathrm{ml} \mathrm{NCS}$ for an additional $3 \mathrm{~h}$. CK2 kinase activity in cell lysates was determined against the synthetic peptide RRRADDSDDDDD.

by wet blotting in $25 \mathrm{mM}$ Tris, $192 \mathrm{mM}$ glycine, $0.1 \%$ SDS, $20 \% \mathrm{MeOH}$. The membrane was blocked in blocking buffer $(0.2 \%$ casein, $0.1 \%$ Tween-20 in PBS) and incubated with either monoclonal anti-AKT, -GSK3 $\beta$ (both from BD Transduction Laboratories, Franklin Lakes, NJ, USA), anti-CK $2 \beta$, -CK $2 \alpha / \alpha^{\prime}$ (both from Calbiochem), anti- $\beta$-actin (Sigma, Brondby, Denmark) or polyclonal anti-PhosphoAKT (Ser473) (Biosource, Invitrogen, Taastrup, Denmark), anti-Phospho-BID (Ser78), -Phospho-BID (Ser61) (both from Bethyl Laboratories, Montgomery, TX, USA), anti-BID (Santa Cruz Biotechnology, Santa Cruz, CA, USA), anti-PhosphoGSK3 $\beta$ (S9) (Cell Signaling Technology, Beverly, MA, USA), anti-CK $2 \alpha^{\prime}$ [obtained by immunizing rabbits with a specific peptide (SQPCADNAVLSSGTAAR)]. After washing in blocking buffer the membranes were incubated with either a secondary goat anti-mouse antibody or goat anti-rabbit coupled to alkaline phosphatase (Jackson ImmunoResearch Laboratories, Suffolk, UK). Visualization was done with CDP-star (Applied Biosystems, Naerum, Denmark) according to the manufacturer's instructions.

Protein kinase activity tests. Protein kinase CK2 activity test was performed for $10 \mathrm{~min}$ at $30^{\circ} \mathrm{C}$ in a total volume of $50 \mu \mathrm{l}$ containing $25 \mathrm{mM}$ Tris- $\mathrm{HCl} \mathrm{pH} 8.5,150 \mathrm{mM} \mathrm{NaCl}, 5 \mathrm{mM}$ $\mathrm{MgCl}_{2}, 1 \mathrm{mMDTT}, 125 \mu \mathrm{M}$ ATP, $0.6 \mu \mathrm{Ci}\left[\gamma^{-32} \mathrm{P}\right]-\mathrm{ATP}(3,000 \mathrm{Ci} /$ mmol, Hartmann Analytic, Braunschweig, Germany), $200 \mu \mathrm{M}$ CK2 peptide (RRRADDSDDDDD, from KinaseDetect ApS) and $5 \mu \mathrm{g}$ whole cell extract. Samples were spotted onto P81 phosphocellulose paper and washed extensively in $0.85 \mathrm{mM}$ phosphoric acid. Incorporation of radiolabeled phosphate was measured by counting samples in a liquid scintillation counter (Canberra-Packard, Downers Grove, IL, USA).

\section{Results}

In order to analyse a possible interplay between members of the PIKK family (ATM and DNA-PKcs) and CK2 in response to neocarzinostatin-induced DNA damage, we focused on BID and AKT1 since these are targets of both a PIKK and CK2. Mouse embryo fibroblasts proficient and deficient in their expression 
A

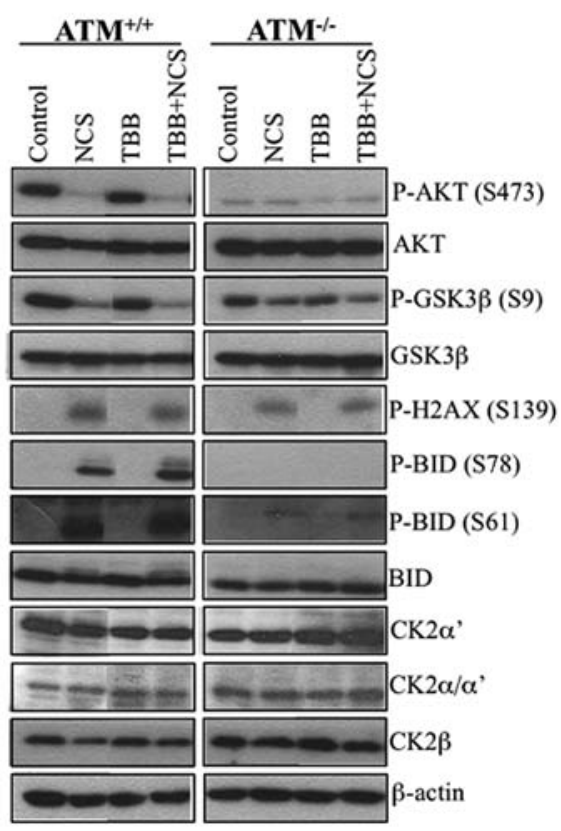

C

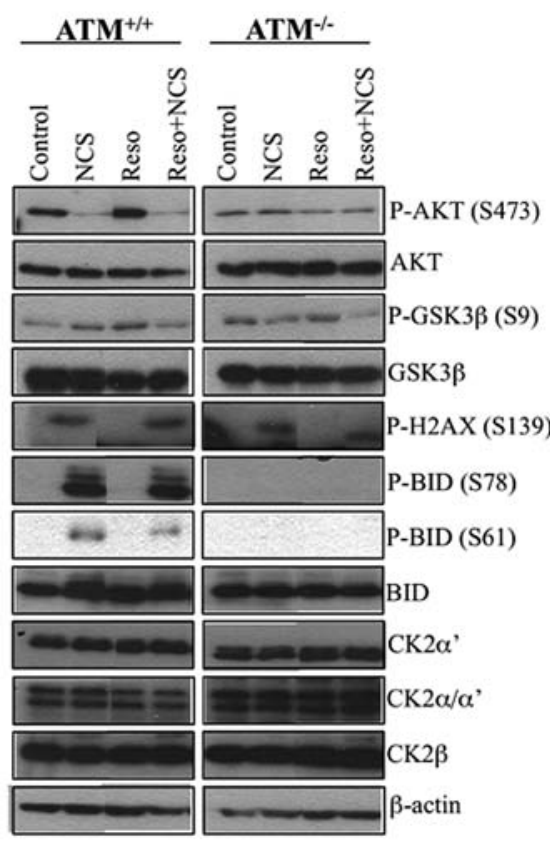

Figure 2. Effects of CK2 inhibitors and DNA double strand break induction on various signaling molecules in $\mathrm{ATM}^{+/+}$and $\mathrm{ATM}^{-/}$mouse embryo fibroblasts. Western blot analysis of mouse embryo fibroblasts $\left(\mathrm{ATM}^{+/+}\right.$and $\left.\mathrm{ATM}^{-/}\right)$preincubated with $50 \mu \mathrm{M}$ TBB (A), $25 \mu \mathrm{M}$ DMAT (B) or $50 \mu \mathrm{M}$ resorufin (C) for $2 \mathrm{~h}$ before addition of $30 \mu \mathrm{g} / \mathrm{ml} \mathrm{NCS}$ for an additional $3 \mathrm{~h}$. As a loading control $\beta$-actin expression was used.

of ATM, were incubated with one of the three CK2 inhibitors TBB (37), DMAT (38) and resorufin (39) in the absence and presence of the radiomimetic drug neocarzinostatin (NCS), which induces DSBs (40). To ensure, that endogenous CK2 was inhibited we measured CK2 activity, and the activity measured in untreated cell lysates of $\mathrm{ATM}^{+/+}$and $\mathrm{ATM}^{-/}$cells was set to $100 \%$ (Fig. 1). Cells were incubated with NCS alone or together with either one of the CK2 inhibitors TBB, DMAT and reso-
B

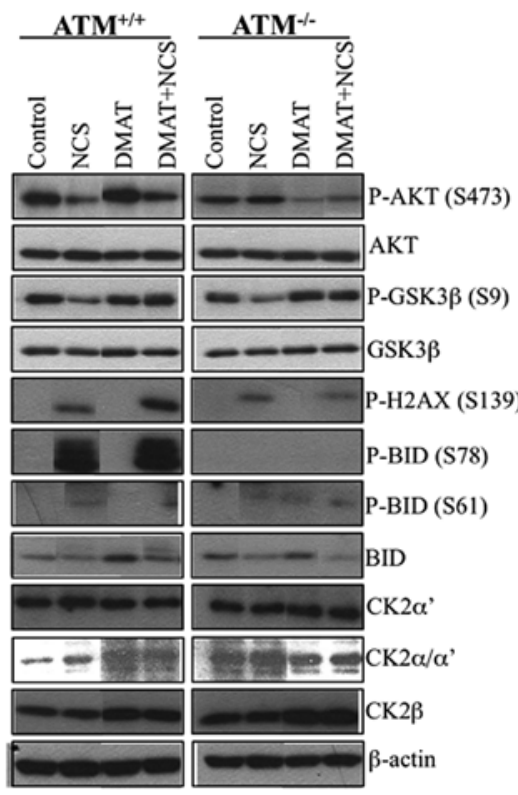

rufin and the various combination treatments as indicated in the figure legend. NCS alone did not have a significant influence on CK2 activity. In contrast treatment with the three established CK2 inhibitors TBB, DMAT and resorufin, led to a significant reduction of endogenous CK2 activity. DMAT treatment led to a loss of approximately $70 \%$ of endogenous CK2 activity, whereas TBB and resorufin attenuated CK 2 activity by 30 and $25 \%$, respectively. The inhibition of CK2 activity was always somewhat higher in $\mathrm{ATM}^{+/+}$cells as compared to cells lacking ATM. Combination treatments, with CK2 inhibitors and NCS did not further influence CK2 activity.

To analyse the effect of the above-mentioned treatments on the signaling molecules AKT1 and BID, Western blot analyses were performed to detect changes in the phosphorylation status and expression levels (Fig. 2). Neocarzinostatin-induced DNA damage in ATM wild-type cells led to a significant reduction in AKT1 S473 phosphorylation (Fig. 2A) in comparison to the untreated control lysate. Treatment of the cells with TBB in the absence and presence of NCS, did not influence the phosphorylation of AKT1 at S473 in comparison to the untreated control lysate (Fig. 2A). Similar results were obtained for DMAT (Fig. 2B) and resorufin (Fig. 2C), respectively. The activity status of AKT1 was confirmed by downstream phosphorylation of GSK3 $\beta$. Fig. 2A shows that concomitant with the decrease in phosphorylation of AKT1 S473, phosphorylation of S9 in GSK3 $\beta$ decreases. The presence of TBB seems to have no influence on the degree of phosphorylation of $\mathrm{S} 9$, similar results were obtained with resorufin (Fig. 2C). However, treatment with DMAT (Fig. 2B) showed strong S9 phosphorylation in NCS treated cells in comparison to the NCS treatment alone.

In ATM mutant cells phosphorylation of the AKT1 S473 residue, did not show any changes upon NCS, TBB and resorufin treatment (Fig. 2A and C), in contrast to that seen in ATM wild-type cells. Furthermore, there appears to be lower background phosphorylation of AKT1 at S473 in $\mathrm{ATM}^{-/}$cells. Although one would expect that the phosphorylation status of GSK3 $\beta$, a direct downstream target of AKT1, should reflect 


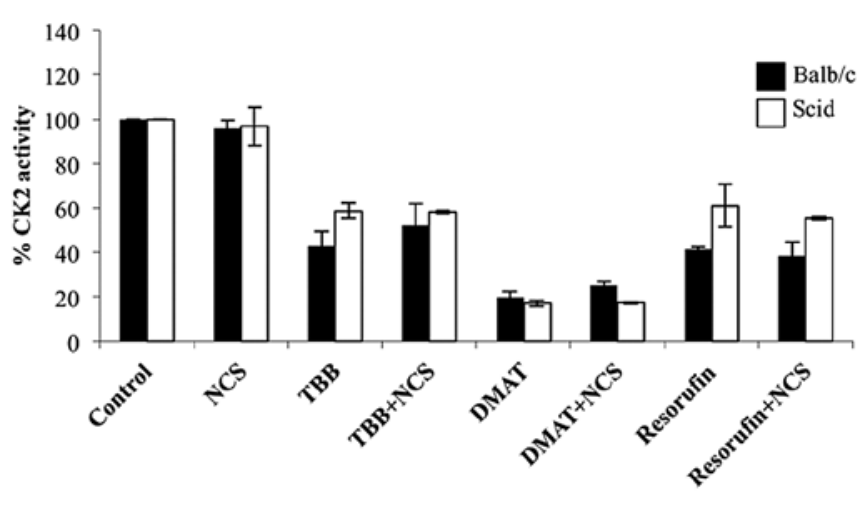

Figure 3. Inhibition of endogenous CK2 by TBB, DMAT and resorufin in the absence and presence of the radiomimetic drug NCS. Mouse fibroblasts [DNA-PKcs proficient (Balb/c) and DNA-PKcs defective (Scid)] were preincubated with $50 \mu \mathrm{M}$ TBB or resorufin or $25 \mu \mathrm{M}$ DMAT for $2 \mathrm{~h}$ before addition of $30 \mu \mathrm{g} / \mathrm{ml} \mathrm{NCS}$ for an additional $3 \mathrm{~h}$. CK2 kinase activity in cell lysates was determined against the synthetic peptide RRRADDSDDDDD in the presence of $125 \mu \mathrm{M}$ ATP.

the phosphorylation status of AKT1, this is not the case in ATM mutant cells with respect to DMAT treatment (Fig. 2B). As already mentioned above P-AKT1 S473 phosphorylation was higher in control and NCS-treated cells, yet the phosphorylation status of GSK $3 \beta$ at S9 was attenuated upon DSB induction irrespective of the presence of CK2 inhibitors TBB and resorufin (Fig. 2A-C). DMAT treatment rescued S9 dephosphorylation in the presence of NCS (Fig. 2B). Both the expression of AKT1 and GSK3 $\beta$ protein, were unaltered with the different treatments and comparable in the two cell lines.

We also investigated the phosphorylation status of BID protein at S78 and S61. Both residues were only phosphorylated upon NCS treatment (Fig. 2A-C) in agreement with published data $(28,29)$ and co-treatment with CK2 inhibitors TBB and DMAT led to a slight increase in the phosphorylation of S78 (Fig. 2A and B), which was not the case with resorufin (Fig. 2C). As a control for the induction of DSBs, we monitored histone H2AX phosphorylation at Ser139 (41). We also investigated the expression levels of three different CK2 subunits. However, no differences were observed between the two cell lines using $\beta$-actin as a loading control, irrespective whether the cells were challenged with CK2 inhibitors or NCS.

Next we performed the same experiments, in a pair of mouse fibroblast cell lines, proficient $(\mathrm{Balb} / \mathrm{c})$ or deficient in a functional catalytic subunit of DNA-PK (Scid). The degree of inhibition of endogenous CK2 activity was measured after incubation of the cell lines with the three CK2 inhibitors DMAT, TBB and resorufin, in the absence and presence of NCS (Fig. 3). As with the ATM cells, the activity in untreated cell lysates for both cell lines was set to $100 \%$. Incubation with NCS had no influence on CK2 activity, either in DNA-PKcs proficient or in DNA-PKcs defective cells. Again, as seen in ATM MEFs, DMAT treatment led to the strongest reduction in CK2 activity, with a residual activity of approximately $20 \%$. Treatment with TBB and resorufin led to an approximate loss of $50 \%$ CK2 activity in DNA-PKcs expressing cells, whereas in the DNA-PKcs mutant cells the CK2 activity loss was less pronounced. Induction of DSBs (treatment with NCS) had no influence in combination with the CK2 inhibitors on the activity of CK2.

Whole cell lysates from cells treated as in Fig. 3, were subjected to Western blot analysis, to detect the expression of AKT1, GSK3 $\beta$, BID and CK2 subunits and the phosphorylation status of P-AKT1 (S473), P-GSK3 $\beta$ (S9), P-BID (S78), $\mathrm{P}-\mathrm{BID}$ (S61). Unlike the ATM cells, there is no decreased phosphorylation of AKT1 at Ser473 in response to neocarzinostatin (Fig. 4). Neither is the phosphorylation altered by the different CK2 inhibitors with the exception of DMAT, which decreased the phosphorylation in both DNA-PKcs wild-type and mutant cells (Fig. 4B). In addition, there is a much higher degree of AKT1 S473 phosphorylation in DNA-PKcs wild-type cells, in accordance with reports, that $\mathrm{S} 473$ is a target of DNA-PK $(33,34)$. Phosphorylation of GSK3 $\beta$ (S9), a downstream target of AKT1, mirrored the AKT1 S473 phosphorylation in DNA-PKcs expressing cells with respect to NCS treatment and also with respect to TBB (Fig. 4A); however, DMAT did not lead to decreased $S 9$ phosphorylation, as was the case for AKT1 S473 (Fig. 4B). Co-treatment with resorufin slightly decreased the phosphorylation of S9 (Fig. 4C). As for DNA-PKcs defective cells, NCS slightly decreased the phosphorylation of S9, which interestingly was not overall decreased in DNA-PKcs defective cells, as was the case with AKT1 S473, suggesting that other kinases can also target S9, besides AKT1. TBB did not affect the S9 phosphorylation of GSK3 $\beta$ (Fig. 4A), however DMAT decreased the phosphorylation (Fig. 4B). In the case of resorufin, the combination with NCS almost completely abolished the phosphorylation of GSK3 $\beta$ S9 although the AKT1 S473 phosphorylation was unaltered (Fig. 4C).

Next, we investigated the phosphorylation status of BID at S78 and S61 in both DNA-PKcs proficient and DNA-PKcs defective cells, yet there was no significant alteration in the phosphorylation status observed. As expected, there was a strong BID phosphorylation observed in cells undergoing NCS treatment (Fig. 4A-C). DSB induction was monitored by analysing the phosphorylation of $\mathrm{H} 2 \mathrm{AX}$ at S139.

The most significant difference observed between the two cell lines is the expression status of CK2 subunits, especially CK $2 \alpha^{\prime}$ and CK2 $\beta$ (Fig. 4A-C). Although the different incubations did not alter the expression of the two subunits, there was an overall increased expression of CK2 $\alpha^{\prime}$ (3-4 times) and CK2 $\beta$ (up to two-fold) in cells lacking DNA-PKcs. The expression of CK $2 \alpha$ was not increased, however, the activity of CK2 was increased by $\sim 1.3$ in the DNA-PKcs defective cells (data not shown).

\section{Discussion}

Protein kinases as therapeutic targets especially in cancer are currently a major focus in academia and the pharmaceutical industry. Many inhibitors with high potency are available, however, the challenge is their selectivity. Herein, we tested three CK2 inhibitors; the selection of different CK2 inhibitors was necessary in order to check whether they lead to the same results. These considerations are based on previous observations that only resorufin shows a very selective CK2 inhibition, in contrast to TBB and DMAT, which have been shown also to inhibit members of the PIKK family (35). This may be due to their chemical nature since TBB and DMAT are 
A

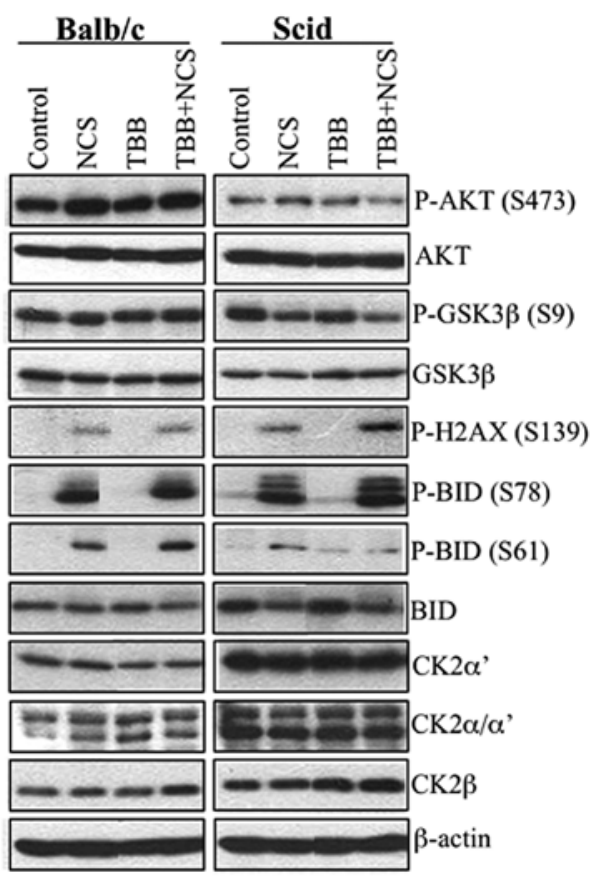

C

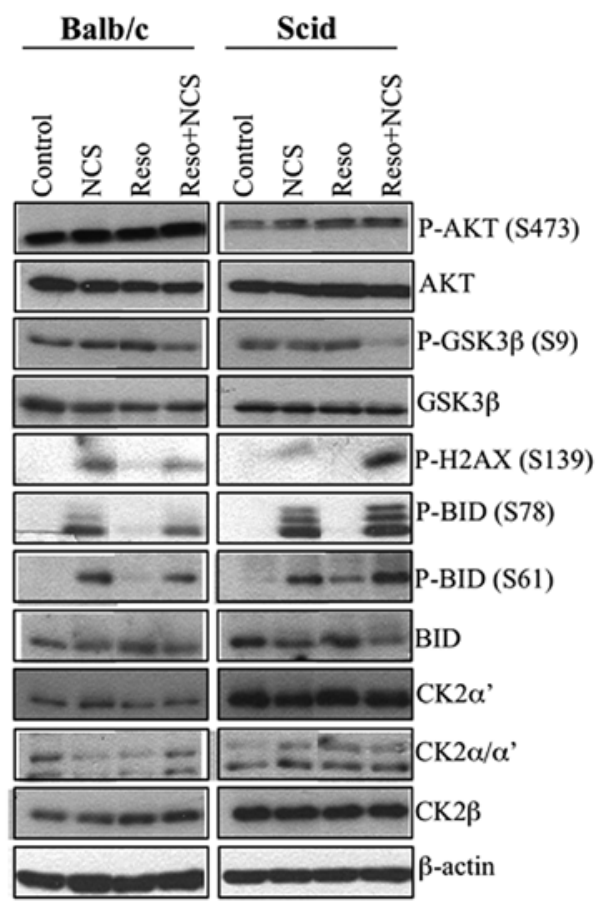

Figure 4. Effects of CK2 inhibitors and DNA double strand break induction on various signaling molecules in DNA-PKcs proficient (Balb/c) and DNAPKcs defective (Scid) mouse fibroblasts. Western blot analysis of mouse fibroblasts pre-incubated with $50 \mu \mathrm{M} \mathrm{TBB}$ (A), $25 \mu \mathrm{M}$ DMAT (B) or $50 \mu \mathrm{M}$ resorufin (C) for $2 \mathrm{~h}$ before addition of $30 \mu \mathrm{g} / \mathrm{ml}$ NCS for an additional $3 \mathrm{~h}$. As a loading control $\beta$-actin expression was used.

polyhalogenated benzimidazoles, whereas resorufin belongs to the phenoxazine-3-ones (reviewed in ref. 42).

Herein, we investigated the effect of the three established protein kinase CK2 inhibitors DMAT, TBB and resorufin on the signaling molecules AKT1/GSK3 $\beta$ and BID. This was done
B

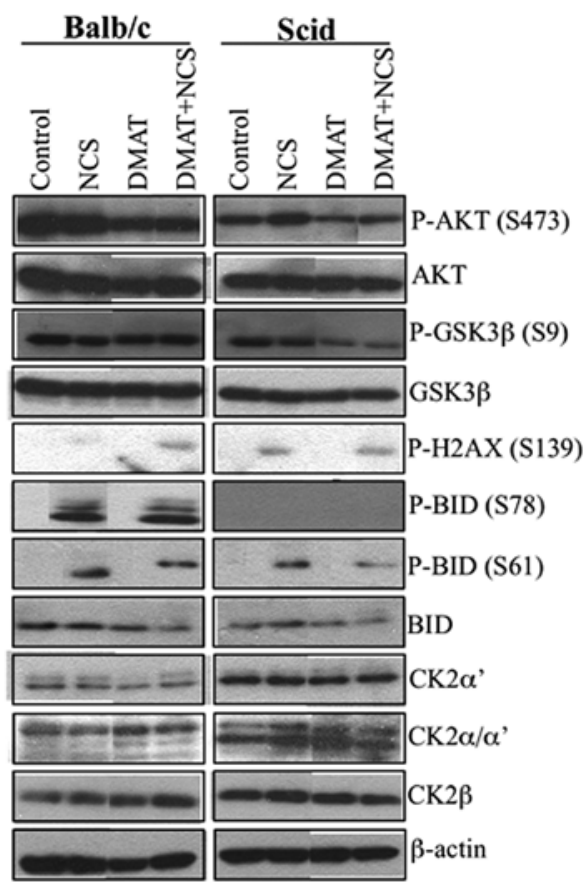

in two pairs of mouse cell lines expressing/lacking a functional member of the PIKK family i.e. ATM and DNA-PKcs, respectively, and in the absence and presence of the radiomimetic drug neocarzinostatin in order to characterize interplay between CK2 and PIKKs.

In accordance with previous data, DMAT is most potent in inhibiting endogenous CK2 activity in both sets of cell lines, followed by TBB and resorufin, although resorufin is the most selective CK2 inhibitor of the three $(35,39)$. All three inhibitors were slightly less potent in the mouse embryo fibroblast cell lines, especially TBB and resorufin. Furthermore, there were no differences in their inhibition of CK2 regardless if the cells were incubated with inhibitor alone or in combination with NCS. This is in agreement with data from Fritz et al, where the incubation of cells with a combination of the genotoxic drug cisplatin in combination with CK2 inhibitors did not change the degree of inhibition compared to incubation with CK2 inhibitor alone (35).

The overexpression of CK2 $\alpha^{\prime}$ and CK2 $\beta$ in DNA-PKcs defective fibroblasts was accompanied by a 1.3 -fold increase in CK2 activity (data not shown) in agreement with previously published data and the increase of CK2 $\alpha^{\prime}$ was also found in human glioblastoma cells (11). However in the glioblastoma cells, there was no increase in CK2 $\beta$, the reason for the increase in CK2 subunits is at present unknown but was also seen at the mRNA level in the human glioblastoma cells (11). No such difference was seen in the ATM pair of cell lines, indicating that it is specific for DNA-PKcs.

In response to DNA damage, BID is phosphorylated by ATM at S78 and S61 $(28,29)$. Since we previously reported that, at least in vitro, CK2 could phosphorylate BID at S76, we were wondering if there was a hierarchical phosphorylation, which is known from CREB and SMC3 $(43,44)$, where a constitutive phosphorylation by CK2 is required for efficient DNA damage induced ATM phosphorylation of a nearby site. However, as 
can be seen from the results with the three inhibitors, this is not the case, since there is no change in the phosphorylation of BID. Regardless of CK2 activity, ATM is able to efficiently phosphorylate BID at S78. In addition, it is confirmed that S78 is an ATM site, since this is not phosphorylated in ATM deficient cells. S61 is weakly phosphorylated confirming previous data, that $\mathrm{S} 61$ can also be targeted by other kinases e.g. CK1 (21).

AKT1 activation and S473 phosphorylation in response to DNA damage are DNA-PK dependent (34). Our data show that in DNA-PKcs defective cells phosphorylation of AKT1 at S473 is attenuated in comparison to wild-type cells (Fig. 4). However, such an attenuation of S473 phosphorylation is also seen in $\mathrm{ATM}^{-/-}$cells (Fig. 2). These results are in line with a recent report from $\mathrm{Li}$ and Yang (45) who compared two isogenic mouse embryonic fibroblast cell lines derived from normal and ATM knockout mice. In normal MEF cells treated with insulin, S473 is readily phosphorylated, whereas S473 phosphorylation is almost completely abolished in $\mathrm{ATM}^{-1-}$ MEF cells.

Our results obtained during the investigations reported here support the notion that DMAT is interfering with DNA damage response in ATM and DNA-PKcs cells. Although the phosphorylation of AKT S473 is already attenuated in ATM and DNA-PKcs defective cells, treatment with DMAT led to an even greater reduction of AKT S473 phosphorylation, which is also the case upon NCS induction (Figs. 2B and 4B). These results are in line with our previous observations (35) that DMAT and TBB also interfere with PI3K and DNA-PKcs activity. The reason that TBB is not showing such a strong effect as DMAT may be owing to the fact that the $\mathrm{K}_{\mathrm{i}}$ values for TBB and DMAT are 0.4 and $0.04 \mu \mathrm{M}$, respectively (for review of CK2 inhibitor $\mathrm{K}_{\mathrm{i}}$, see ref. 42). Hence, DMAT has a considerably higher potency towards CK2 but also towards other kinases such as the PIKKs.

Overexpression of CK $2 \alpha$ has been shown to correlate with metastatic risk in breast carcinomas (46), poor prognosis in human colorectal carcinoma (47), and acute myeloid leukemia (48). However, in contrast to the reported observations with respect to $\mathrm{CK} 2 \alpha$ no detailed information exists for the isozyme CK $2 \alpha^{\prime}$. This is not surprising since the isozymes cannot be distinguished with respect to their activity. At present the only possibility to distinguish both isozymes is by antibody detection. CK $2 \alpha^{\prime}$ has been shown to be elevated in testis and in brain (3). Whereas in testis the role of CK2 $\alpha^{\prime}$ has been established to be important for the maturation into fertile spermatocytes, the possible role in brain is lacking. Hence at present we do not know what the overexpression of $\mathrm{CK} 2 \alpha^{\prime}$ will cause in the various scenarios, e.g. in glioblastoma cell defective in DNA-PKcs (11) and in Scid mouse cells also devoid of a functional DNA-PKcs. However, one should keep in mind that the glioblastoma cell lines were derived from a tumor and other factors, owing to the many chromosomal aberrations, may influence the observed elevated CK2 activity and $\mathrm{CK} 2 \alpha^{\prime}$ expression, so the correlation with a lack of functional DNA-PKcs is more apparent than real. Hence, the results, obtained here are based on normal cells, with a normal karyotype and moreover in another species, strongly support a correlation between lack of DNA-PKcs and increase of CK2 subunits.

\section{Acknowledgements}

This work was supported by grants from the Danish Cancer Society to OGI (DP07109) and the Deutsche Forschungsgemeinschaft to GF (DFG FR 1241/5-3).

\section{References}

1. St-Denis NA and Litchfield DW: Protein kinase CK2 in health and disease: From birth to death: the role of protein kinase CK2 in the regulation of cell proliferation and survival. Cell Mol Life Sci 66: 1817-1829, 2009.

2. Guerra B and Issinger OG: Protein kinase CK2 in human diseases. Curr Med Chem 15: 1870-1886, 2008.

3. Guerra B, Siemer S, Boldyreff B and Issinger OG: Protein kinase CK2: evidence for a protein kinase CK2 beta subunit fraction, devoid of the catalytic CK2alpha subunit, in mouse brain and testicles. FEBS Lett 462: 353-357, 1999.

4. Xu X, Toselli PA, Russell LD and Seldin DC: Globozoospermia in mice lacking the casein kinase II alpha' catalytic subunit. Nat Genet 23: 118-121, 1999.

5. Olsen BB, Boldyreff B, Niefind K and Issinger OG: Purification and characterization of the CK2alpha'-based holoenzyme, an isozyme of CK2alpha: a comparative analysis. Protein Expr Purif 47: 651-661, 2006.

6. Lou DY, Dominguez I, Toselli P, Landesman-Bollag E, O'Brien C and Seldin DC: The alpha catalytic subunit of protein kinase $\mathrm{CK} 2$ is required for mouse embryonic development. Mol Cell Biol 28: 131-139, 2008.

7. Lempiäinen $\mathrm{H}$ and Halazonetis TD: Emerging common themes in regulation of PIKKs and PI3Ks. EMBO J 28: 3067-3073, 2009.

8. Mahaney BL, Meek K and Lees-Miller SP: Repair of ionizing radiation-induced DNA double-strand breaks by non-homologous end-joining. Biochem J 417: 639-650, 2009.

9. Allalunis-Turner MJ, Barron GM, Day RS III, Dobler KD and Mirzayans R: Isolation of two cell lines from a human malignant glioma specimen differing in sensitivity to radiation and chemotherapeutic drugs. Radiat Res 134: 349-354, 1993.

10. Olsen BB, Issinger OG and Guerra B: Regulation of DNAdependent protein kinase by protein kinase CK2 in human glioblastoma cells. Oncogene 29: 6016-6026, 2010.

11. Olsen BB, Fischer U, Rasmussen TL, Montenarh M, Meese E, Fritz $G$ and Issinger OG: Lack of the catalytic subunit of DNA-dependent protein kinase (DNA-PKcs) is accompanied by increased CK2 $\alpha$ ' levels. Mol Cell Biochem: July 13, 2011 (Epub ahead of print) doi: 10.1007/s11010-011-0954-7.

12. Derheimer FA and Kastan MB: Multiple roles of ATM in monitoring and maintaining DNA integrity. FEBS Lett 584: 3675-3681, 2010.

13. Spycher C, Miller ES, Townsend K, Pavic L, Morrice NA, Janscak P, Stewart GS and Stucki M: Constitutive phosphorylation of MDC1 physically links MRE11-RAD50-NBS1 complex to damaged chromatin. J Cell Biol 181: 227-240, 2008.

14. Melander F, Bekker-Jensen S, Falck J, Bartek J, Mailand N and Lukas J: Phosphorylation of SDT repeats in the MDC1 N-terminus triggers retention of NBS1 at the DNA damagemodified chomatin. J Cell Biol 181: 213-226, 2008.

15. Stucki M and Jackson SP: gammaH2AX and MDC1: anchoring the DNA-damage-response machinery to broken chromosomes. DNA Repair 5: 534-543, 2006.

16. Meek DW, Simon S, Kikkawa U and Eckhart W: The p53 tumour suppressor protein is phosphorylated at serine 389 by casein kinase II. EMBO J 9: 3253-3260, 1990.

17. Götz C, Scholtes P, Prowald A, Schuster N, Nastainczyk W and Montenarh M: Protein kinase CK2 interacts with a multi-protein binding domain of p53. Mol Cell Biochem 191: 111-120, 1999.

18. Hjerrild M, Milne D, Dumaz N, Hay T, Issinger OG and Meek D: Phosphorylation of murine double minute clone 2 (MDM2) protein at serine- 267 by protein kinase CK2 in vitro and in cultured cells. Biochem J 355: 347-356, 2001.

19. Loizou JI, El-Khamixy SF, Zlatanou A, Moore DJ, Chan DW Qin J, Sarno S, Meggio F, Pinna LA and Caldecott KW: The protein kinase CK2 facilitates repair of chromosomal DNA single-strand breaks. Cell 117: 17-28, 2004.

20. Koch CA, Agyei R, Galicia S, Metalnikov P, O'Donnell P, Starostine A, Weinfeld $M$ and Durocher D: Xrcc4 physically links DNA end processing by polynucleotide kinase to DNA ligation by DNA ligase IV. EMBO J 23: 3874-3885, 2004. 
21. Desagher S, Osen-Sand A, Montessuit S, Magnenat E, Vilbois F, Hochmann A, Journot L, Antonsson B and Martinou JC: Phosphorylation of bid by casein kinases I and II regulates its cleavage by caspase 8. Mol Cell 8: 601-611, 2001.

22. Olsen BB, Petersen J and Issinger OG: BID, an interaction partner of protein kinase CK2alpha. Biol Chem 387: 441-449, 2006.

23. Guerra B, Issinger OG and Wang JY: Modulation of human checkpoint kinase Chk1 by the regulatory beta-subunit of protein kinase CK2. Oncogene 22: 4933-4942, 2003.

24. Bjørling-Poulsen M, Siehler S, Wiesmüller L, Meek D, Niefind K and Issinger OG: The 'regulatory' beta-subunit of protein kinase CK2 negatively influences p53-mediated allosteric effects on Chk2 activation. Oncogene 24: 6194-6200, 2005.

25. Kim ST: Protein kinase CK2 interacts with Chk2 and phosphorylates Mre11 on serine 649. Biochem Biophys Res Commun 331: 247-252, 2005.

26. Di Maira G, Salvi M, Arrigoni G, Marin O, Sarno S, Brustolon F, Pinna LA and Ruzzene M: Protein kinase CK2 phosphorylates and upregulates Akt/PKB. Cell Death Differ 12: 668-677, 2005.

27. Guerra B: Protein kinase CK2 subunits are positive regulators of AKT kinase. Int J Oncol 28: 685-693, 2006.

28. Kamer I, Sarig R, Zaltsman Y, Niv H, Oberkovitz G, Regev L, Haimovich G, Lerenthal Y, Marcellus RC and Gross A: Proapoptotic BID is an ATM effector in the DNA-damage response. Cell 122: 593-603, 2005.

29. Zinkel SS, Hurov KE, Ong C, Abtahi FM, Gross A and Korsmeyer SJ: A role for proapoptotic BID in the DNA-damage response. Cell 122: 579-591, 2005.

30. Zinkel SS, Ong CC, Ferguson DO, Iwasaki H, Akashi K, Bronson RT, Kutok JL, Alt FW and Korsmeyer SJ: Proapoptotic BID is required for myeloid homeostasis and tumor suppression. Genes Dev 17: 229-239, 2003.

31. Kastan MB: Cell biology: A BID for the pathway. Nature 437: 1103, 2005.

32. Feng J, Park J, Cron P, Hess D and Hemmings BA: Identification of a PKB/Akt hydrophobic motif Ser-473 kinase as DNA-dependent protein kinase. J Biol Chem 279: 41189-41196, 2004.

33. Surucu B, Bozulic L, Hynx D, Parcellier A and Hemmings BA: In vivo analysis of protein kinase $B$ (PKB)/Akt regulation in DNA-PKcs-null mice reveals a role for PKB/Akt in DNA damage response and tumorigenesis. J Biol Chem 283: 30025-30033, 2008.

34. Bozulic L, Surucu B, Hynx D and Hemmings BA: PKBalpha/ Akt1 acts downstream of DNA-PK in the DNA double-strand break response and promotes survival. Mol Cell 30: 203-213, 2008.

35. Fritz G, Issinger OG and Olsen BB: Selectivity analysis of protein kinase CK2 inhibitors DMAT, TBB and resorufin in cisplatininduced stress responses. Int J Oncol 35: 1151-1157, 2010.

36. Biedermann KA, Sun J, Giaccia AJ, Tosto LM and Brown JM: Scid mutation in mice confers hypersensitivity to ionizing radiation and a deficiency in DNA double-strand break repair. Proc Natl Acad Sci USA 88: 1394-1397, 1991.
37. Sarno S, Reddy H, Meggio F, Ruzzene M, Davies SP Donella-Deana A, Shgar D and Pinna LA: Selectivity of 4,5,6,7-tetrabromobenzotriazole, an ATP site-directed inhibitor of protein kinase CK2 ('casein kinase-2'). FEBS Lett 496: 44-48, 2001.

38. Pagano MA, Meggio F, Ruzzene M, Andrzejewska M, Kazimierczuk $Z$ and Pinna LA: 2-Dimethylamino-4,5,6,7tetrabromo-1H-benzimidazole: a novel powerful and selective inhibitor of protein kinase CK2. Biochem Biophys Res Commun 321: 1040-1044, 2004

39. Sandholt IS, Olsen BB, Guerra B and Issinger OG: Resorufin: a lead for a new protein kinase CK2 inhibitor. Anticancer Drugs 20: 238-248, 2009.

40. Povirk LF: DNA damage and mutagenesis by radiomimetic DNA-cleaving agents: bleomycin, neocarzinostatin and other enediynes. Mutat Res 355: 71-89, 1996.

41. Bonner WM, Redon CE, Dickey JS, Nakamura AJ, Sedelnikova OA, Solier S and Pommier Y: GammaH2AX and cancer. Nat Rev Cancer 8: 957-967, 2008.

42. Cozza G, Meggio F and Moro S: The dark side of protein kinase CK2 inhibition. Curr Med Chem 18: 2867-2884, 2011.

43. Shanware NP, Trinh AT, Williams LM and Tibbetts RS: Coregulated ataxia telangiectasia-mutated and casein kinase sites modulate cAMP-response element-binding protein-coactivator interactions in response to DNA damage. J Biol Chem 282: 6283-6291, 2007.

44. Luo H, Li Y, Mu JJ, Zhang J, Tonaka T, Hamamori Y, Jung SY, Wang Y and Qin J: Regulation of intra-S phase checkpoint by ionizing radiation (IR)-dependent and IR-independent phosphorylation of SMC3. J Biol Chem 283: 19176-19183, 2008

45. Li Y and Yang DQ: The ATM inhibitor KU-55933 suppresses cell proliferation and induces apoptosis by blocking Akt in cancer cells with overactivated Akt. Mol Cancer Ther 9: $113-125,2010$.

46. Giusiano S, Cochet C, Filhol O, Duchemin-Pelletier E, Secq V, Bonnier P, Carcopino X, Boubli L, Birnbaum D, Garcia S, Iovanna J and Charpin C: Protein kinase CK2 $\alpha$ subunit overexpression correlates with metastatic risk in breast carcinomas: quantitative immunohistochemistry in tissue microarrays. Eur J Cancer 47: 792-801, 2011.

47. Lin KY, Tai C, Hsu JC, Li CF, Fang CL, Lai HC, Hseu YC, Lin YF and Uen YH: Overexpression of nuclear protein kinase CK $2 \alpha$ catalytic subunit $(\mathrm{CK} 2 \alpha)$ as a poor prognosticator in human colorectal cancer. PLoS One 6: e17193, 2011.

48. Kim JS, Eom JI, Cheong JW, Choi AJ, Lee JK, Yang WI and Min YH: Protein kinase CK2alpha as an unfavorable prognostic marker and novel therapeutic target in acute myeloid leukemia. Clin Cancer Res 13: 1019-1028, 2007. 